\title{
A question of scale: Replication and the effective evaluation of conservation interventions
}

\author{
Amanda M. Bennett ${ }^{a b}$, Jessica Steiner ${ }^{b}$, Sue Carstairs ${ }^{c}$, Andrea Gielens ${ }^{b}$, and Christina M. Davy ${ }^{\text {de* }}$ \\ ${ }^{a}$ Biology Department, Trent University, 2140 East Bank Drive, Peterborough, ON K9J 7B8, Canada; \\ ${ }^{\mathrm{b}}$ Wildlife Preservation Canada, 5420 Highway 6 North, Guelph, ON N1H 6J2, Canada; ${ }^{\mathrm{c} O n t a r i o}$ Turtle \\ Conservation Centre, 4-1434 Chemong Road, Selwyn, ON K9J 6X2, Canada; ${ }^{d}$ Wildlife Research and \\ Monitoring Section, Ontario Ministry of Natural Resources and Forestry, 2140 East Bank Drive, \\ Peterborough, ON K9J 7B8, Canada; ${ }^{e}$ Environmental and Life Sciences, Trent University, 1600 West \\ Bank Drive, Peterborough, ON K9J 7B8, Canada
}

*christina.davy@ontario.ca

\section{Abstract}

Conservation interventions can keep critically endangered species from going extinct and stabilize threatened populations. The species-specific, case-by-case approaches and small sample sizes inherent to applied conservation measures are not well suited to scientific evaluations of outcomes. Debates about whether a method "works" become entrenched in a vote-counting framework. Furthermore, population-level replication is rare but necessary for disentangling the effects of an intervention from other drivers of population change. Turtle headstarting is a conservation tool that has attracted strong opinions but little robust data. Logistical limitations, such as those imposed by the long lives of turtles, have slowed experimental evaluation and constrained the use of replication or experimental controls. Headstarting project goals vary among projects and stakeholders, and success is not always explicitly defined. To facilitate robust evaluations, we provide direction for data collection and reporting to guide the application of conservation interventions in logistically challenging systems. We offer recommendations for standardized data collection that allow their valuable results to contribute to the development of best practices, regardless of the magnitude of the project. An evidence-based and collaborative approach will lead to improved program design and reporting, and will facilitate constructive evaluation of interventions both within and among conservation programs.

Key words: evidence-based conservation, reporting standards, data collection, turtle conservation, meta-analysis

\section{The Conservation Scientist's Prayer}

FSM, grant me the serenity to accept there are questions I cannot answer [yet], the data to answer the questions I can, and the wisdom to know the difference.

-The Authors

\section{Introduction}

Rapid, human-impact-linked, global declines in biodiversity are a growing conservation concern (Dirzo et al. 2014). In the face of precipitous losses, applied conservation interventions have 
successfully slowed or reversed population declines in many species (e.g., Griffiths and Pavajeau 2008; Martin et al. 2012). Interventions used to prevent extirpation include supplemental feeding, establishing genetic assurance populations, reintroductions, translocations, or removal of invasive species or non-native predators (Fischer and Lindenmayer 2000; Scott et al. 2005). The regional, and often highly localized, nature of conservation efforts has resulted in a case-by-case application of individual techniques to a range of species. This in turn has resulted in variable methodology, sample sizes, and outcomes among projects. Furthermore, data collection and peer-reviewed publication of outcomes may not be a priority, or even a feasible option, for many conservation practitioners. Negative results are also rarely published (Knight 2009), and success is not always clearly defined. Thus, the efficacy of conservation interventions is difficult to evaluate via comparison among projects (Kapos et al. 2008). Consequently, there is controversy and disagreement in the literature about whether particular methods "work" (Pullin and Knight 2009).

The appropriate conservation intervention to prevent extinction depends on the biology of the target population or species and the threats it faces (Scott et al. 2005). The evaluation of effectiveness and reporting of circumstances from previous applications is critical to develop best practices for an intervention. However, evaluations of the overall effectiveness of a conservation intervention (i.e., "does it work?") often use vote counting, where the number of projects perceived as successes and failures is tallied to determine an overall score (Stewart 2010; Koricheva and Gurevitch 2013). Vote counting has been widely criticized, and its statistical drawbacks are numerous; results are inherently biased because studies of different sample sizes are given equal weight (one vote), and small sample sizes are less likely to provide significant results (Friedman 2001; Scheiner and Gurevitch 2001; Hedges and Olkin 2014). Vote counting results in either accepting or discounting a tool, rather than focusing on the circumstances in which the tool was applied (e.g., Ricciardi and Simberloff 2009; Miteva et al. 2012). This approach creates a polarized, yes-or-no framework that is poorly suited to evaluating conservation interventions in complex, real-world situations, limiting critical discussion about appropriate applications of conservation tools.

We argue that "does it work?" (e.g., Dodd and Seigel 1991; Mitrus 2005; Pérez-Buitrago et al. 2008; Miteva et al. 2012) is overly simplistic and reduces our ability to effectively evaluate conservation interventions. First, "does it work?" is difficult to answer without a consistent, explicit definition of a "working" intervention. This definition may vary widely among studies (e.g., Mitrus 2005; Pérez-Buitrago et al. 2008). Second, even if the term is clearly defined, the question still leads directly to a limiting yes or no response. We suggest that this language may stymie conservation efforts and creativity by discouraging the testing of techniques that may prove appropriate and valuable for particular conservation efforts. We are obviously unable to use the peer-reviewed literature to quantify how many conservation interventions have not been tested. However, in the course of our conservation work we have experienced several examples of "does it work?" approaches preventing "risky" but potentially useful research on conservation intervention. To provide one example, one of us observed two senior researchers at a conference sharing their strong opinions that a particular conservation intervention "does not work" (this is a direct quote, and they are of course entitled to their expert opinions). No evidence was provided at the time, and these strong statements led directly to a graduate student changing the focus of their research away from that intervention, despite the fact that its efficacy has never been rigorously evaluated.

We suggest that the critical questions for evaluation of conservation interventions should be whether application of the method achieves the explicitly defined objectives of the intervention (e.g., stabilizing or reversing a population decline, increasing the survivorship of an age-class, expanding the range of the species, or establishing a viable assurance population). The success of most interventions will depend on the details, so projects should also experimentally evaluate best practices (e.g., husbandry, 
release techniques, timing and frequency of species removal) for applying conservation interventions (Pullin and Knight 2009; Smith et al. 2010).

A major challenge in evaluating conservation successes is defining the scale of evaluation, and then finding adequate and appropriate replicates at that scale. When testing the impact of a conservation intervention on individual fitness, sample size is equal to the number of individuals in the treatment and control groups. However, if the objective is to evaluate the impact of an intervention on population growth, then the sample size is equal to the number of study populations involved. One cannot evaluate the effectiveness of an intervention on population growth rates by studying a single population, no matter how much research is done on that population. The level of replication for such an analysis is the population; therefore, the sample size is one. In an experimental framework, the proper comparison would be among multiple populations in which the conservation intervention is applied and several control populations, where site-level differences are accounted for in a quantitative analysis. Evaluating the population-level effects of conservation techniques therefore requires either studying multiple populations at once, or meta-analytical approaches that pool data from multiple projects (e.g., Marczak et al. 2010; Branton and Richardson 2011).

In this paper, we examine the practice of inadequate replication in evaluations of conservation interventions. We selected turtle headstarting as an example to illustrate our concerns because we have worked directly with this method, and because it has generated a great deal of controversy, advocacy, criticism, and debate in the literature. Despite decades of peer-reviewed studies on headstarting in single populations (reviewed by Burke 2015), the method itself has not yet received a great deal of hypothesis-driven or evidence-based evaluation. This is partly due to turtles' long-lived life history strategies. Turtles are one of the most vulnerable vertebrate groups in the world, with approximately half of the described species listed as threatened with extinction (Turtle Conservation Coalition 2011). Most species of turtle are long-lived, exhibit delayed sexual maturity, and experience high embryo and juvenile predation rates (Gibbons 1987; Wilbur and Morin 1988; Congdon et al. 1994). Recovery from population-level mortality events is extremely slow, requiring several decades (Brooks et al. 1991; Congdon et al. 1993, 1994; Doak et al. 1994; Heppell et al. 1996; Heppell 1998). This life history complicates conservation efforts, particularly where multiple, emergent threats exist (e.g., Crawford et al. 2014).

The goal of turtle headstarting is to boost recruitment to declining populations (Burke 2015), but recruitment to reproductive age classes is rarely measured directly, and is not compared with appropriate control populations. Thus, arguments on both sides of the debate remain largely based on within-population analyses, despite decades of excellent research on particular populations (e.g., Mitrus 2005; Shaver and Rubio 2008; Nagy et al. 2015). To provide context to our discussion, we briefly review the historical application of headstarting as a conservation tool for turtles. Next, we examine the current critique of headstarting and ask how success has been measured in turtle headstarting to date. We then examine evaluations of headstarting at different scales of analyses. Finally, we advocate for a hypothesis-testing framework that recognizes the limitations of data collection at different scales, recommends appropriate data collection and communication at those scales, and ultimately facilitates meaningful comparisons among conservation projects.

All data have value, but not all data can answer the same questions. It is not our intention to prescribe one set of methods to all conservation projects, but rather to encourage projects of all sizes to maximize their potential impact. To this end, we offer clear criteria for success at various timescales, and clarify the appropriate units of comparison for scientific evaluation. Large, well-funded projects with an explicit research component may have the capacity to collect and analyze large data sets. Smaller, purely applied projects can increase their conservation impact by contributing their results to larger meta-analyses, with minimal additional effort or cost. A lack of data collection during individual 
conservation intervention projects does not diminish their potential impact on the target population(s), and data collection may not be of interest to all project managers. Nevertheless, a collaborative approach in which relevant projects of all sizes and capacities collect and share standardized data can expand their collective impact, providing evidence-based tools that can be more broadly applied to wildlife conservation, and that are adaptable to a variety of circumstances.

\section{Example intervention: Headstarting}

\section{What is headstarting?}

Headstarting refers to the ex situ rearing of individuals hatched in captivity from wild eggs or collected as hatchlings from the wild (Burke 2015). Originally established on an experimental basis for endangered sea turtles (Pritchard 1979), headstarting programs are now increasingly used in recovery programs for tortoises and freshwater turtles (Seigel and Dodd 2000). The goal of headstarting is to circumvent low hatching success and (or) high mortality of juveniles to increase recruitment, often by accelerating growth in captivity (Moll and Moll 2000), resulting in stabilized or increased population growth rates (Frazer et al. 1990; Iverson 1991; Spinks et al. 2003). Headstarting can also be used to rear turtles for reintroduction (van Leuven et al. 2006; Buhlmann et al. 2015). Once turtles hatch in captivity, they may be released soon after hatching (often termed artificial incubation: García et al. 2003), or reared indoors for some amount of time before translocation into native habitat (e.g., Haskell et al. 1996; Mitrus 2005; Buhlmann et al. 2015; Nagy et al. 2015). Below, we use turtle headstarting to highlight the problem of evaluating conservation interventions at appropriate scales, drawing from our own experiences in freshwater turtle headstarting and examples from relevant literature.

Headstarting and captive breeding are generally evaluated as separate conservation interventions. However, in the absence of parental care, the experience of the hatchling turtle, whether from a wild or captive-sourced egg, is ultimately the same-protection in captivity until release. Thus, evaluations of headstarting as an intervention can encompass projects using turtle eggs from any source, although selective pressures (e.g., local adaptation, artificial selection) warrant consideration in evaluations of post-release success. Although this selection is unlikely to be as strong in captive turtles because of their different mating strategies and long generation times (but see Jensen et al. 2015), selection on hatchery-raised fish can have major impacts on post-release survival (Le Cam et al. 2015; Jensen et al. 2016), and this possibility should not be discounted in other taxa.

\section{Critiques of the headstarting method for turtles}

Whether turtle headstarting boosts recruitment to populations has generated much controversy and debate (Woody 1990; Heppell et al. 1996; Seigel and Dodd 2000). Some of the concerns raised about headstarting reflect a lack of post-release monitoring and reporting of individual turtle outcomes, resulting in speculation about the relative fitness of headstarted turtles and health of headstarted populations. Critics point out that habituation to captivity could affect predator avoidance (Frazer 1992; Meylan and Ehrenfeld 2000), foraging (East and Ligon 2013), and habitat selection behaviours (Okuyama et al. 2010). Headstarts from temperate populations kept active year-round in captivity to maximize growth will lack overwintering experience prior to release, potentially compromising post-release over-wintering survivorship (Frazer 1992; Bjorndal et al. 2003). Furthermore, omitting overwintering can reduce reproductive potential in smooth green snake (Opheodrys vernalis) headstarts, where brumation appears necessary to trigger gametogenesis (Sacerdote-Velat et al. 2014). This may also prove to be a concern for turtles.

Critics have also raised concerns about the spread of disease from captive to wild populations (Flanagan 2000; Moll and Moll 2000; Seigel and Dodd 2000). Disease management is a critical 
component of any captive management program, and the introduction of novel pathogens or increases in the prevalence of endemic pathogens can devastate a declining population. However, disease management relates directly to the management of captive populations prior to release, rather than to the effectiveness of headstarting (or any other conservation intervention). Headstarting programs can largely eliminate disease concerns by adhering to strict biological controls in captivity and assessing disease risk prior to reintroductions (e.g., Jakob-Hoff et al. 2014). The conflation of concerns around disease management and concerns about the effectiveness of headstarting further illustrates the need for replicated, experimentally structured evaluations of this conservation method. Disease is a potential confounding factor that could threaten the success of particular projects, but is unlikely to affect many projects equally. In a vote-counting "does it work?" framework, conflating poor husbandry and disease management with headstarting itself would result in "votes" against the efficacy of headstarting, even though disease would be responsible for the poor results.

Other critiques of turtle headstarting arise from demographic models investigating the relative impact of headstarting in comparison to increasing adult survivorship on population growth rates. Elasticity analyses of population models show that adult female survivorship has the highest impact on population growth rates, and several authors have interpreted these results to mean that efforts to increase juvenile recruitment are better spent on protecting adults (Congdon et al. 1993; Heppell et al. 1996; Heppell 1998; Mitrus 2005; Enneson and Litzgus 2008). These criticisms tend to focus on headstarting in isolation, without consideration for concurrent mitigation of the initial causes of population declines (Dodd and Seigel 1991; Frazer 1992; Heppell 1998; Meylan and Ehrenfeld 2000; Vander Haegen et al. 2009; Smeenk 2010; Crawford et al. 2014). Models incorporating multiple conservation actions may be more realistic and may lead to more successful management plans for threatened populations. For example, models of conservation interventions for turtle populations simultaneously impacted by road mortality and nest predation showed that reducing adult mortality is insufficient to increase population growth rate without simultaneous nest protection (Crawford et al. 2014).

Furthermore, elasticity values based on theoretical models may not accurately represent biological reality, as interpretation of model outcomes is restricted by assumptions (i.e., time invariance, density independence, and population sex ratio) that do not necessarily reflect real-world population dynamics (Benton and Grant 1999). A lack of information on survivorship and growth rates of wild juvenile turtles also results in model parameters estimated from similar species or other life-history stages (e.g., Heppell et al. 1996; Mitrus 2005), which may not accurately represent the target population. Although modelling exercises and elasticity analyses can lead to valuable insights for the focus of conservation efforts (e.g., Doak et al. 1994; Govindarajulu et al. 2005), it is important to remember that models are hypotheses to be tested and refined rather than perfect reflections of population processes. Uncritical acceptance of model outcomes, particularly under a vote-counting paradigm, may mislead conservation efforts away from what could otherwise be effective interventions.

\section{How has success been measured?}

As with other types of intervention, definitions of success vary considerably among headstarting projects, though they are largely segregated into the attainment of either short- or long-term goals (Haskell et al. 1996; US Fish \& Wildlife Service 2001; Buhlmann et al. 2015; Burke 2015). Shortterm goals generally reflect the one- to three-year funding windows characteristic of many conservation programs, and may include a target number of headstarts successfully released (Nelson et al. 2009; Kuhns 2010; Ontario Wood Turtle Recovery Team 2010), and (or) post-release survivorship of headstarts monitored using telemetry (Hazard and Morafka 2002; Mitrus 2005; Parks Canada 2012). Long-term goals include increases in population size or distribution, or changes in age structure, that reflect a stable or growing population (US Fish \& Wildlife Service 2001; 
Vermont Fish \& Wildlife Department 2009). Few programs have reported on long-term goals, though there is some limited evidence of headstarts surviving to adulthood (Bell et al. 2005), reproducing (Vander Haegen et al. 2009), and apparently altering the age structure of a population (Spinks et al. 2003). Details of rearing techniques may not be described in the literature (e.g., Haskell et al. 1996; Mogollones et al. 2010; Bona et al. 2012), and few studies explicitly compare success of headstarted individuals to wild individuals (but see Spinks et al. 2003; Mitrus 2005). Rigorous, scientific evaluation of headstarting requires standardization, permanent marking of released headstarts, post-release monitoring, and accessible reporting of population parameters among projects, all of which are exceedingly limited. Most of all, scientific evaluation of headstarting requires a data set with replication at the population level-evaluation of the intervention as a tool for general use cannot be done by any study of a single population, no matter how excellent. Although individual projects have been successful at meeting their stated goals and outcomes, these vary among projects. Despite decades of turtle headstarting around the globe, comparable data from multiple headstarted and control populations are not available, and consequently, there are no published population-level meta-analyses of the effectiveness of headstarting on conserving turtle populations.

\section{Effective evaluation}

Effective evaluation of any intervention requires a priori consideration of the scale of the project. The perceived dichotomy of short- vs. long-term goals can discourage practitioners leading smallscale projects from data collection and reporting, data that can be used to inform meta-analyses and evaluations at a broad scale. Valuable information regarding individual performance metrics, rearing conditions, or even just the number of individuals released into a population in each year can be collected and reported for most projects, even those with severe financial, temporal, or logistical constraints on post-release monitoring and population-level comparisons. Small scale, populationor project-specific data can be used to inform broader scale evaluations and the development of best practices by incorporation into meta-analyses (Fig. 1). We emphasize the need for the recording and reporting of data at all project scales, and demonstrate this continuing with our example of turtle headstarting.

\section{Impacts within individuals}

How does an intervention affect the individual? Many headstarting programs accelerate hatchling growth rates beyond those of wild turtles, to ensure large body sizes before release (e.g., Haskell et al. 1996; Vermont Fish \& Wildlife Department 2009; Parks Canada 2012). The fine-scale relationship between body size and survivorship in wild hatchling turtles is unclear, with equivocal evidence both for and against the "bigger is better" hypothesis (Janzen 1993; Haskell et al. 1996; Congdon et al. 1999; Janzen et al. 2000; Delmas et al. 2007; Paterson et al. 2014; Canessa et al. 2016). Although sub-adult and adult freshwater turtles do experience lower mortality rates than juveniles (Enneson and Litzgus 2008), growth is energetically costly, and the physiological trade-offs of accelerated juvenile growth are not well understood (Wieser 1994; Bayne 2000; Dmitriew et al. 2009; Dmitriew 2011). Reported data on individual health and fitness outcomes in relation to captiverearing conditions can inform best practices for optimal growth rates and husbandry of headstarted turtles, and inform survivorship and individual growth rate estimates in population models.

\section{Impacts within populations}

Single-population studies can evaluate the fitness of wild-hatched relative to headstarted individuals in a common habitat but cannot generalize about the effectiveness of headstarting on populations. If the objectives of a conservation intervention include evaluation of the impact on the target 


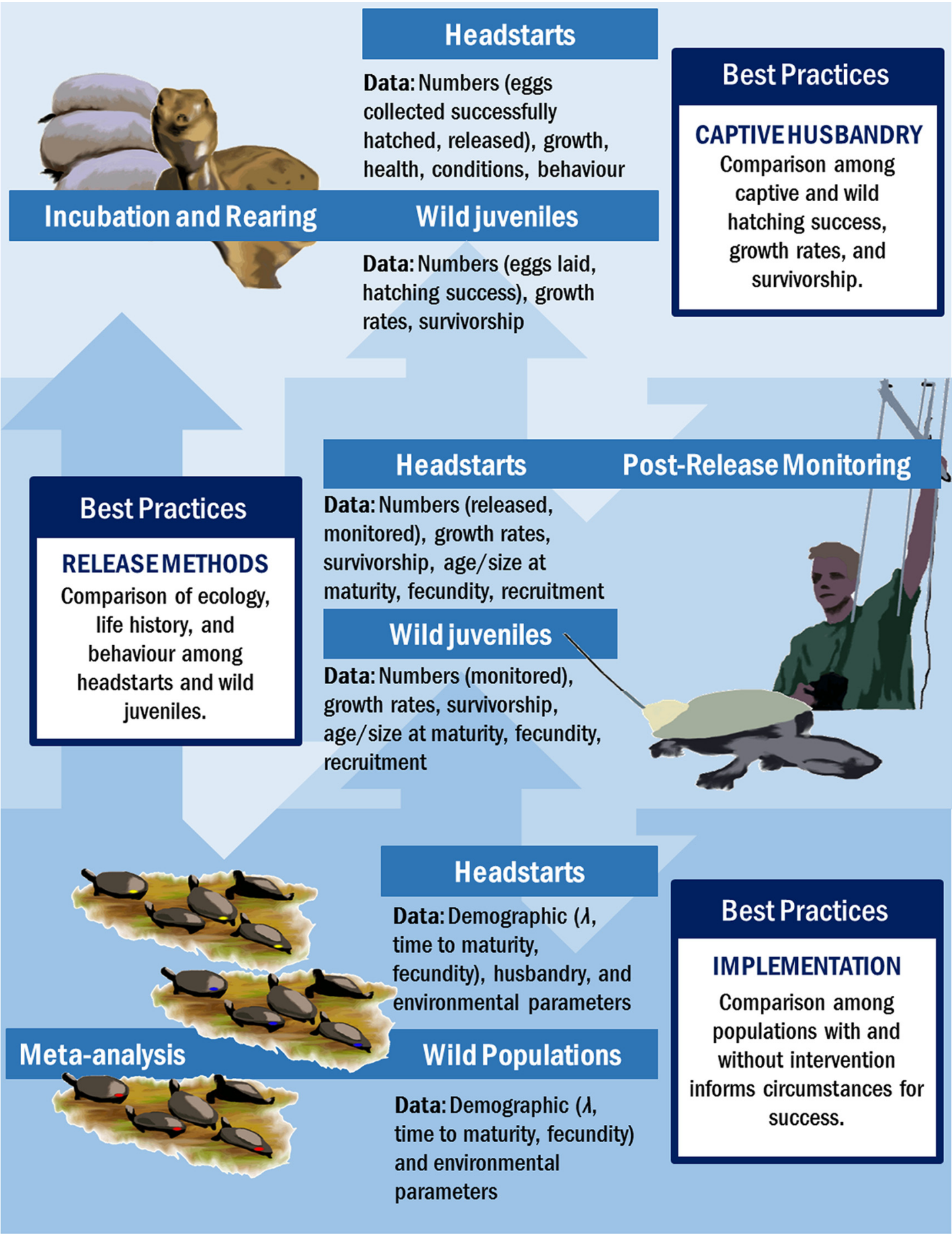

Fig. 1. Illustration of how reportable data (e.g., population growth rate $(\lambda)$ ), at different program scales (incubation, rearing, post-release monitoring), from wild populations and populations undergoing an intervention can inform evaluation and development of best practices at all levels, using headstarting as an example. 
population ("success", as defined by the project), there must be a robust post-intervention monitoring program. This is not a novel suggestion (Armstrong et al. 2007; Seddon et al. 2007; IUCN/SSC 2013; Parker et al. 2013), yet post-intervention monitoring is still not incorporated into many projects that explicitly aim to stabilize their target populations. Tracking growth, behaviour, or survivorship of headstarts alone, although valuable, cannot inform demographic evaluations (unless the population is a reintroduction and there are no wild turtles besides headstarts), because wild juvenile freshwater turtles experience high mortality compared with adults (Congdon et al. 1993). Therefore, the impact of headstart survivorship on a population is only informative in comparison with the survivorship of wild-hatched individuals in the target population, and an experimental approach should be used to compare the fitness of these two groups (Spinks et al. 2003; Mitrus 2005; Attum and Cutshall 2015). However, making the comparison presumes that there are wild-hatched juveniles in the population, which may not be the case when natural recruitment is effectively zero (e.g., Ontario Wood Turtle Recovery Team 2010) or when re-establishing populations within a historical range (e.g., Amaral 2007). Furthermore, headstarted and wild-hatched individuals must be distinguishable in the field, e.g., through non-harmful marking such as passive integrated transponders (Gibbons and Andrews 2004), visible implant elastomer (Davy et al. 2010; Antwis et al. 2014; Simon and Dörner 2014; Kozłowski et al. 2017), or other tools (Auger-Méthé and Whitehead 2007; Parker et al. 2013; Schoen et al. 2015). For example, short-term survival rates have been compared in wild and headstarted plains garter snakes (Thamnophis radix) of similar size (King and Stanford 2006), Mona Island iguanas (Cyclura cornuta stejnegeri; Pérez-Buitrago et al. 2008), and European pond turtles (Emys orbicularis; Mitrus 2005). However, biological fitness is difficult to quantify in turtles, where survivorship and fecundity require decades for direct measurement. Proxies such as individual growth rate, body condition, physiological health, movement behaviour, or site fidelity are often used (Shaver 1999; Shaver and Rubio 2008; Canessa et al. 2016), though we suggest cautious interpretation of these proxies, as they are not all equally informative (e.g., Davy et al. 2014).

\section{Impacts among populations}

Meta-analytic approaches can be used to identify the characteristics of interventions that have been successfully applied, with results being used to optimize the efforts of new and ongoing programs. We currently lack available, standardized data at the individual and within-population scales, limiting our capacity for an among-population, global review of turtle headstarting. Empirical data on the behavior, ecology, and movement of wild juvenile turtles are extremely limited (Ultsch et al. 2007; Paterson et al. 2012; Whitear et al. 2017), but necessary to inform best practices for release-site selection and release timing, as well as for the parameterization of population growth models evaluating headstarting. With advancements in tracking technology towards smaller and lighter tags, we can now follow hatchling turtles and obtain comparative, size-specific survivorship estimates from wild populations (e.g., Paterson et al. 2012). Ideally, post-release monitoring of headstarted turtles is paired with similar studies on wild juvenile survivorship and movement patterns.

To facilitate meta-analyses of turtle headstarting and other interventions such as translocations or predator removal, we provide examples of data collection requirements that would also facilitate evaluation of impacts within projects and help develop best practices for the target intervention (Fig. 1). We suggest that an openly available reporting platform (e.g., conservationevidence.com, open access academic journals), coupled with open standards for reporting data and methodological detail (e.g., conservationmeasures.org), would greatly improve comparison among projects. Although we emphasize the need for reporting of data at any project scale, we recognize that academic publication may present a substantial barrier to some conservation project. We, therefore, encourage open access, online archiving of information on any platform (e.g., publication of year-end reports on a project website). 


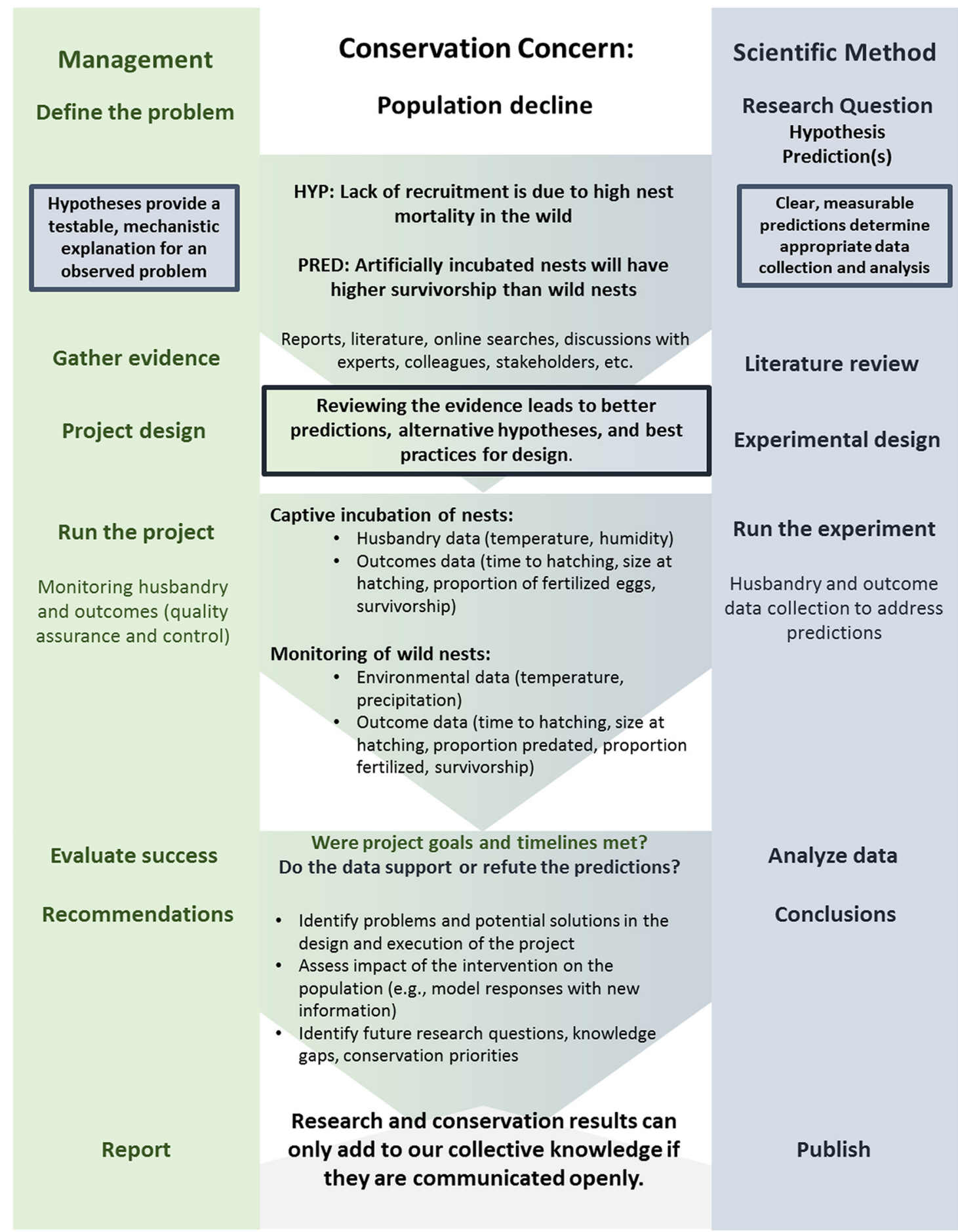

Fig. 2. Illustration of the parallels between project management and the scientific method, with emphasis on the value of incorporating scientific method principles (e.g., hypotheses (HYP) and prediction (PRED)). 


\section{The way forward: Evidence-based best practices}

No conservation intervention is suitable for all situations, but most interventions are useful when applied appropriately, using evidence-based best practices (e.g., Moehrenschlager and Moehrenschlager 2006; Soorae 2016). Thus, asking whether a conservation intervention such as turtle headstarting "works" is simply asking the wrong question. Projects working to conserve threatened populations should first define their goals (e.g., increased population size, juvenile survivorship, or reproductive output). They can then assess whether they have achieved these targets and, if so, which specific husbandry, release, and post-release strategies were most effective. An appropriate post-intervention monitoring program should ideally follow any conservation intervention. Most importantly, any population-specific study cannot be generalized to evaluate a conservation intervention for all other populations in need of applied conservation actions.

Standardized techniques and experimental design would allow individual headstarting projects to contribute not just to the persistence of their target populations, but also to the global effort to conserve turtle species. Incorporating experimental design into conservation interventions wherever possible, including explicitly defined control groups, allows comparison of outcomes with those of other, similar programs. With basic application of the scientific method, data collection can be targeted to address specific predictions, or goals, for the project (Fig. 2). Data collected with a predetermined purpose facilitates statistical analyses, and provides a baseline for quality control. Coupling conservation interventions such as headstarting with rigorous and standardized data collection and reporting will inform the development of best practices documents, increasing the success of conservation projects through empirical evidence and shared experience. It is time to replace the problematic dichotomy of "does it work?" with the less succinct but more useful question "when and how does an intervention achieve the measurable, explicitly-defined goals of the project?" This shift will allow continued improvement of conservation interventions to the benefit of global biodiversity.

We acknowledge that there are projects in which stakeholders do not feel the need to quantify the effects of their intervention, and many projects that are severely limited by available resources. As a group of authors that include both conservation practitioners and academics, we understand that conservation practitioners' capacity to disseminate results varies, as does the academic incentive to publish applied projects. Whether a project is evaluated does not influence its result-unevaluated projects can ultimately have as great or as small a conservation impact as robustly evaluated projects, and may indeed be critical stabilizing forces for threatened populations. Thus, unreported results do not detract from a project's potential impact on its target population or species. However, making results available (including negative ones) allows the conservation community to learn from a project's experience, thus achieving broader impact beyond the target population. Peer-reviewed literature is not the only acceptable form of communication; reports summarizing available data posted online will make them publicly available for future, peer-reviewed meta-analyses. We strongly believe that we can all benefit from increased data collection and sharing in conservation interventions. Therefore, we invite practitioners and academics to work together to maximize the impacts of their conservation efforts by evaluating and optimizing the available tools, and communicating their results.

\section{Acknowledgements}

This paper was inspired by discussions at a workshop on the use of headstarting for effective conservation. We thank the Toronto Zoo and Wildlife Preservation Canada for their support of the workshop. We are grateful for the input and suggestions of the other workshop participants: K. Berieault, W. Bertacchi, G. Bourget, S. Gillingwater, S. Giguere, J. Hathaway, B. Johnson, M. Lafleche, L. Lazure, A. Lentini, N. Mandrak, C. Maisonneuve, P. Paradis, S. Pelletier, J. Philips, J. Rouse, N. Tessier, and E. Williams. J. Litzgus provided helpful comments on an earlier version of the manuscript. 


\section{Author contributions}

AMB, JS, SC, AG, and CMD conceived and designed the study. AMB, JS, SC, AG, and CMD contributed resources. $\mathrm{AMB}$, JS, and CMD drafted or revised the manuscript.

\section{Competing interests}

The authors have declared that no competing interests exist.

\section{Data accessibility statement}

All relevant data are within the paper.

\section{References}

Amaral M. 2007. Northern red-bellied cooter (Pseudemys rubriventris) 5-year review: summary and evaluation. US Fish and Wildlife Service, New England Field Office, Concord, New Hampshire. $39 \mathrm{p}$.

Antwis RE, Purcell R, Walker SL, Fidgett AL, and Preziosi RF. 2014. Effects of visible implanted elastomer marking on physiological traits of frogs. Conservation Physiology, 2(1): cou042. PMID: 27293663 DOI: 10.1093/conphys/cou042

Armstrong DP, Castro I, and Griffiths R. 2007. Using adaptive management to determine requirements of re-introduced populations: the case of the New Zealand hihi. Journal of Applied Ecology, 44(5): 953-962. DOI: 10.1111/j.1365-2664.2007.01320.x

Attum O, and Cutshall CD. 2015. Movement of translocated turtles according to translocation method and habitat structure. Restoration Ecology, 23(5): 588-594. DOI: 10.1111/rec.12233

Auger-Méthé M, and Whitehead H. 2007. The use of natural markings in studies of long-finned pilot whales (Globicephala melas). Marine Mammal Science, 23(1): 77-93. DOI: 10.1111/j.17487692.2006.00090.x

Bayne BL. 2000. Relations between variable rates of growth, metabolic costs and growth efficiencies in individual Sydney rock oysters (Saccostrea commercialis). Journal of Experimental Marine Biology and Ecology, 251(2): 185-203. PMID: 10960614 DOI: 10.1016/S0022-0981(00)00211-2

Bell CDL, Parsons J, Austin TJ, Broderick AC, Ebanks-Petrie G, and Godley BJ. 2005. Some of them came home: the Cayman Turtle Farm headstarting project for the green turtle Chelonia mydas. Oryx, 39(2): 137-148. DOI: 10.1017/S0030605305000372

Benton TG, and Grant A. 1999. Elasticity analysis as an important tool in evolutionary and population ecology. Trends in Ecology \& Evolution, 14(12): 467-471. PMID: 10542452 DOI: 10.1016/ S0169-5347(99)01724-3

Bjorndal KA, Bolten AB, Dellinger T, Delgado CA, and Martins HR. 2003. Compensatory growth in oceanic loggerhead sea turtles: response to a stochastic environment. Ecology, 84(5): 1237-1249. DOI: 10.1890/0012-9658(2003)084[1237:CGIOLS]2.0.CO;2

Bona M, Novotny M, Danko S, and Buresova A. 2012. Headstarting in a small population of European pond turtles (Emys orbicularis) in Central European conditions: first results. Herpetology Notes, 5: 547-550. 
Branton M, and Richardson JS. 2011. Assessing the value of the umbrella-species concept for conservation planning with meta-analysis. Conservation Biology, 25(1): 9-20. PMID: 21091767 DOI: $10.1111 / j .1523-1739.2010 .01606 . x$

Brooks RJ, Brown GP, and Galbraith DA. 1991. Effects of a sudden increase in natural mortality of adults on a population of the common snapping turtle (Chelydra serpentina). Canadian Journal of Zoology, 69(5): 1314-1320. DOI: 10.1139/z91-185

Buhlmann KA, Koch SL, Butler BO, Tuberville TD, Palmero VJ, Bastarache BA, et al. 2015. Reintroduction and head-starting: tools for Blanding's turtle (Emydoidea blandingii) conservation. Herpetological Conservation and Biology, 10(1): 436-454.

Burke RL. 2015. Head-starting turtles: learning from experience. Herpetological Conservation and Biology, 10(1): 299-308.

Canessa S, Genta P, Jesu R, Lamagni L, Oneto F, Salvidio S, et al. 2016. Challenges of monitoring reintroduction outcomes: insights from the conservation breeding program of an endangered turtle in Italy. Biological Conservation, 204: 128-133. DOI: 10.1016/j.biocon.2016.05.003

Congdon JD, Dunham AE, and van Loben Sels RC. 1993. Delayed sexual maturity and demographics of Blanding's turtles (Emydoidea blandingii): implications for conservation and management of longlived organism. Conservation Biology, 7(4): 826-833. DOI: 10.1046/j.1523-1739.1993.740826.x

Congdon JD, Dunham AE, and van Loben Sels RC. 1994. Demographics of common snapping turtles (Chelydra serpentina): implications for conservation and management of long-lived organisms. Integrative \& Comparative Biology, 34(3): 397-408. DOI: 10.1093/icb/34.3.397

Congdon JD, Nagle RD, Dunham AE, Beck CW, Kinney OM, and Yeomans SR. 1999. The relationship of body size to survivorship of hatchling snapping turtles (Chelydra serpentina): an evaluation of the "bigger is better" hypothesis. Oecologia, 121(2): 224-235. PMID: 28308562 DOI: $10.1007 /$ s004420050924

Crawford BA, Maerz JC, Nibbelink NP, Buhlmann KA, and Norton TM. 2014. Estimating the consequences of multiple threats and management strategies for semi-aquatic turtles. Journal of Applied Ecology, 51(2): 359-366. DOI: 10.1111/1365-2664.12194

Davy CM, Coombes SM, Whitear AK, and Mackenzie AS. 2010. Visible implant elastomer: a simple, non-harmful method for marking hatchling turtles. Herpetological Review, 41(4): 442-445.

Davy CM, Paterson JE, and Leifso AE. 2014. When righting is wrong: performance measures require rank repeatability for estimates of individual fitness. Animal Behaviour, 93: 15-23. DOI: 10.1016/j. anbehav.2014.04.013

Delmas V, Baudry E, Girondot M, and Prevot-Julliard AC. 2007. The righting response as a fitness index in freshwater turtles. Biological Journal of the Linnean Society, 91(1): 99-109. DOI: 10.1111/ j.1095-8312.2007.00780.x

Dirzo R, Young HS, Galetti M, Ceballos G, Isaac NJB, and Collen B. 2014. Defaunation in the Anthropocene. Science, 345(6195): 401-406. PMID: 25061202 DOI: 10.1126/science.1251817

Dmitriew C. 2011. The evolution of growth trajectories: what limits growth rate? Biological Reviews, 86(1): 97-116. PMID: 20394607 DOI: 10.1111/j.1469-185X.2010.00136.X 
Dmitriew C, Carroll J, and Rowe L. 2009. Effects of early growth conditions on body composition, allometry, and survival in the ladybird beetle Harmonia axyridis. Canadian Journal of Zoology, 87(2): 175-182. DOI: 10.1139/Z09-001

Doak D, Kareiva P, and Klepetka B. 1994. Modeling population viability for the desert tortoise in the western Mojave Desert. Ecological Applications, 4(3): 446-460. DOI: 10.2307/1941949

Dodd CK Jr, and Seigel RA. 1991. Relocation, repatriation, and translocation of amphibians and reptiles: are they conservation strategies that work? Herpetologica, 47: 336-350.

East MB, and Ligon DB. 2013. Comparison of diet among reintroduced and wild juvenile alligator snapping turtles (Macrochelys temminckii) and adult female Ouachita map turtles (Graptemys ouachitensis). The Southwestern Naturalist, 58(4): 450-458. DOI: 10.1894/0038-4909-58.4.450

Enneson JJ, and Litzgus JD. 2008. Using long-term data and a stage-classified matrix to assess conservation strategies for an endangered turtle (Clemmys guttata). Biological Conservation, 141(6): 1560-1568. DOI: 10.1016/j.biocon.2008.04.001

Fischer J, and Lindenmayer DB. 2000. An assessment of the published results of animal relocations. Biological Conservation, 96(1): 1-11. DOI: 10.1016/S0006-3207(00)00048-3

Flanagan J. 2000. Disease and health considerations. In Turtle conservation. Edited by MW Klemens. Smithsonian Institution Press, Washington, D.C. pp. 85-95.

Frazer NB. 1992. Sea turtle conservation and halfway technology. Conservation Biology, 6(2): 179-184. DOI: $10.1046 / j .1523-1739.1992 .620179 . x$

Frazer NB, Gibbons JW, and Greene JL. 1990. Life tables of a slider turtle population. In Life history and ecology of the slider turtle. Edited by JW Gibbons. Smithsonian Institution Press, Washington, D.C. pp. 183-200.

Friedman L. 2001. Why vote-count reviews don't count. Biological Psychiatry, 49(2): 161-162. DOI: $10.1016 /$ S0006-3223(00)01075-1

Garciía A, Ceballos G, and Adaya R. 2003. Intensive beach management as an improved sea turtle conservation strategy in Mexico. Biological Conservation, 111(2): 253-261. DOI: 10.1016/ S0006-3207(02)00300-2

Gibbons JW. 1987. Why do turtles live so long? Bioscience, 37(4): 262-269. DOI: 10.2307/1310589

Gibbons JW, and Andrews KM. 2004. PIT tagging: simple technology at its best. Bioscience, 54(5): 447-454. DOI: 10.1641/0006-3568(2004)054[0447:PTSTAI]2.0.CO;2

Govindarajulu P, Altwegg R, and Anholt BR. 2005. Matrix model investigation of invasive species control: bullfrogs on Vancouver Island. Ecological Applications, 15(6): 2161-2170. DOI: 10.1890/05-0486

Griffiths RA, and Pavajeau L. 2008. Captive breeding, reintroduction, and the conservation of amphibians. Conservation Biology, 22(4): 852-861. PMID: 18616746 DOI: $10.1111 /$ j.1523-1739.2008.00967.x

Haskell A, Graham TE, Griffin CR, and Hestbeck JB. 1996. Size related survival of headstarted redbelly turtles (Pseudemys rubriventris) in Massachusetts. Journal of Herpetology, 30(4): 524-527. DOI: $10.2307 / 1565695$ 
Hazard LC, and Morafka DJ. 2002. Comparative dispersion of neonate and headstarted juvenile desert tortoises (Gopherus agassizii): a preliminary assessment of age effects. Chelonian Conservation and Biology, 4(2): 406-409.

Hedges LV, and Olkin I. 2014. Statistical methods for meta-analysis. Academic Press, London, UK. $369 \mathrm{p}$.

Heppell SS. 1998. Application of life-history theory and population model analysis to turtle conservation. Copeia, 1998: 367-375. DOI: 10.2307/1447430

Heppell SS, Crowder LB, and Crouse DT. 1996. Models to evaluate headstarting as a management tool for long-lived turtles. Ecological Applications, 6(2): 556-565. DOI: 10.2307/2269391

IUCN/SSC. 2013. Guidelines for reintroductions and other conservation translocations. Version 1.0. IUCN/SSC, Gland, Switzerland.

Iverson JB. 1991. Patterns of survivorship in turtles (order Testudines). Canadian Journal of Zoology, 69(2): 385-391. DOI: 10.1139/z91-060

Jakob-Hoff RM, MacDiarmid SC, Lees C, Miller PS, Travis D, and Kock R. 2014. Manual of procedures for wildlife disease risk analysis. World Organisation for Animal Health, Paris, France. Published in association with the International Union for Conservation of Nature and the Species Survival Commission.

Janzen FJ. 1993. An experimental analysis of natural selection on body size of hatchling turtles. Ecology, 74(2): 332-341. DOI: 10.2307/1939296

Janzen FJ, Tucker JK, and Paukstis GL. 2000. Experimental analysis of an early life-history stage: avian predation selects for larger body size of hatchling turtles. Journal of Evolutionary Biology, 13(6): 947-954. DOI: 10.1046/j.1420-9101.2000.00234.x

Jensen AJ, Berg M, Bremset G, Finstad B, Hvidsten NA, Jensås JG, et al. 2016. Passing a seawater challenge test is not indicative of hatchery-reared Atlantic salmon Salmo salar smolts performing as well at sea as their naturally produced conspecifics. Journal of Fish Biology, 88(6): 2219-2235. PMID: 27133912 DOI: $10.1111 / \mathrm{jfb} .12984$

Jensen EL, Tapia W, Caccone A, and Russello MA. 2015. Genetics of a head-start program to guide conservation of an endangered Galápagos tortoise (Chelonoidis ephippium). Conservation Genetics, 16(4): 823-832. DOI: $10.1007 /$ s10592-015-0703-7

Kapos V, Balmford A, Aveling R, Bubb P, Carey P, Entwistle A, et al. 2008. Calibrating conservation: new tools for measuring success. Conservation Letters, 1: 155-164. DOI: 10.1111/j.1755-263X. 2008.00025.x

King RB, and Stanford KM. 2006. Headstarting as a management tool: a case study of the Plains Gartersnake. Herpetologica, 62(3): 282-292. DOI: 10.1655/0018-0831(2006)62[282:HAAMTA]2.0.CO;2

Knight AT. 2009. Is conservation biology ready to fail? Conservation Biology, 23(3): 517. PMID: 22748088 DOI: 10.1111/j.1523-1739.2009.01222.x

Koricheva J, and Gurevitch J. 2013. Place of meta-analysis among other methods of research synthesis. In Handbook of meta-analysis in ecology and evolution. Edited by J Koricheva, J Gurevitch, and K Mengersen. Princeton University Press, Princeton, New Jersey. pp. 3-13. 
Kozłowski M, Szczepkowski M, Wunderlich K, Piotrowska I, and Szczepkowska B. 2017. Effect of visible implant elastomers on the growth, survival and tag retention in juvenile Atlantic sturgeon (Acipenser oxyrinchus) in laboratory conditions. Aquaculture Research, 48(4): 1849-1855. DOI: $10.1111 /$ are.13022

Kuhns AR. 2010. Recovery of the Blanding's turtle (Emydoidea blandingii) at Spring Bluff Nature Preserve, Lake County Forest Preserves. Final Report, Federal Aid Project T-39-D-1, Lake County Forest Preserve District and Illinois Natural History Survey. Illinois Department of Natural Resources, Springfield, Illinois.

Le Cam S, Perrier C, Besnard A-L, Bernatchez L, and Evanno G. 2015. Genetic and phenotypic changes in an Atlantic salmon population supplemented with non-local individuals: a longitudinal study over 21 years. Proceedings of the Royal Society B, 282(1802): 20142765. PMID: 25608883 DOI: $10.1098 / \mathrm{rspb} .2014 .2765$

Marczak LB, Sakamaki T, Turvey SL, Deguise I, Wood SLR, and Richardson JS. 2010. Are forested buffers an effective conservation strategy for riparian fauna? An assessment using meta-analysis. Ecological Applications, 20(1): 126-134. PMID: 20349835 DOI: 10.1890/08-2064.1

Martin TG, Nally S, Burbidge AA, Arnall S, Garnett ST, Hayward MW, et al. 2012. Acting fast helps avoid extinction. Conservation Letters, 5: 274-280. DOI: 10.1111/j.1755-263X.2012.00239.x

Meylan AB, and Ehrenfeld D. 2000. Conservation of marine turtles. In Turtle conservation. Edited by MW Klemens. Smithsonian Institution Press, Washington, D.C. pp. 96-125.

Miteva DA, Pattanayak SK, and Ferraro PJ. 2012. Evaluation of biodiversity policy instruments: what works and what doesn't? Oxford Review of Economic Policy, 28(1): 69-92. DOI: 10.1093/oxrep/grs009

Mitrus S. 2005. Headstarting in European pond turtles (Emys orbicularis): does it work? AmphibiaReptilia, 26(3): 333-341. DOI: 10.1163/156853805774408504

Moehrenschlager A, and Moehrenschlager C. 2006. Population census of reintroduced swift foxes (Vulpes velox) in Canada and northern Montana 2005/2006. Centre for Conservation Research Report No. 1, Calgary Zoo, Calgary, Alberta.

Mogollones SC, Rodríguez DJ, Hernández O, and Barreto GR. 2010. A demographic study of the Arrau Turtle (Podocnemis expansa) in the Middle Orinoco River, Venezuela. Chelonian Conservation and Biology, 9(1): 79-89. DOI: 10.2744/CCB-0778.1

Moll EO, and Moll D. 2000. Conservation of river turtles. In Turtle conservation. Edited by MW Klemens. Smithsonian Institution Press, Washington, D.C. pp. 125-155.

Nagy KA, Hillard LS, Tuma MW, and Morafka DJ. 2015. Head-started desert tortoises (Gopherus agassizii): movements, survivorship and mortality causes following their release. Herpetological Conservation and Biology, 10(1): 203-215.

Nelson DH, Langford GJ, Borden JA, and Turner WM. 2009. Reproductive and hatchling ecology of the Alabama red-bellied cooter (Pseudemys alabamensis): implications for conservation and management. Chelonian Conservation and Biology, 8(1): 66-73. DOI: 10.2744/CCB-0744.1

Okuyama J, Shimizu T, Abe O, Yoseda K, and Arai N. 2010. Wild versus head-started hawksbill turtles Eretmochelys imbricata: post-release behavior and feeding adaptions. Endangered Species Research, 10: 181-190. DOI: 10.3354/esr00250 
Ontario Wood Turtle Recovery Team. 2010. Recovery strategy for the Wood Turtle (Glyptemys insculpta) in Ontario, Ontario recovery strategy series. Ontario Ministry of Natural Resources, Goulais River, Ontario. 48 p.

Parker KA, Ewen JG, Seddon PJ, and Armstrong DP. 2013. Post-release monitoring of bird translocations: why is it important and how do we do it. Notornis, 60(1): 85-92.

Parks Canada. 2012. Recovery strategy for the Blanding's turtle (Emydoidea blandingii), Nova Scotia population, in Canada [Final version]. Species at Risk Act Recovery Strategy Series. Parks Canada, Ottawa, Ontario. $41 \mathrm{p}$.

Paterson JE, Steinberg BD, and Litzgus JD. 2012. Revealing a cryptic life-history stage: differences in habitat selection and survivorship between hatchlings of two turtle species at risk (Glyptemys insculpta and Emydoidea blandingii). Wildlife Research, 39(5): 408-418. DOI: 10.1071/WR12039

Paterson JE, Steinberg BD, and Litzgus JD. 2014. Effects of body size, habitat selection and exposure on hatchling turtle survival. Journal of Zoology, 294(4): 278-285. DOI: 10.1111/jzo.12176

Pérez-Buitrago N, García MA, Sabat A, Delgado J, Álvarez A, McMillan O, et al. 2008. Do headstart programs work? Survival and body condition in headstarted Mona Island iguanas Cyclura cornuta stejnegeri. Endangered Species Research, 6: 55-65. DOI: 10.3354/esr00130

Pritchard PCH. 1979. 'Head-starting' and other conservation techniques for marine turtles Cheloniidae and Dermochelyidae. International Zoo Yearbook, 19(1): 38-42. DOI: 10.1111/ j.1748-1090.1979.tb00522.x

Pullin AS, and Knight TM. 2009. Doing more good than harm-building an evidence-base for conservation and environmental management. Biological Conservation, 142(5): 931-934. DOI: 10.1016/j. biocon.2009.01.010

Ricciardi A, and Simberloff D. 2009. Assisted colonization is not a viable conservation strategy. Trends in Ecology \& Evolution, 24(5): 248-253. PMID: 19324453 DOI: 10.1016/j.tree.2008.12.006

Sacerdote-Velat AB, Earnhardt JM, Mulkerin D, Boehm D, and Glowacki G. 2014. Evaluation of headstarting and release techniques for population augmentation and reintroduction of the smooth green snake. Animal Conservation, 17(S1): 65-73. DOI: 10.1111/acv.12151

Scheiner SM, and Gurevitch J (Editors). 2001. Design and analysis of ecological experiments. Oxford University Press, New York City, New York. 432 p.

Schoen A, Boenke M, and Green DM. 2015. Tracking toads using photo identification and imagerecognition software. Herpetological Review, 46(2): 188-192.

Scott JM, Goble DD, Wiens JA, Wilcove DS, Bean M, and Male T. 2005. Recovery of imperiled species under the Endangered Species Act: the need for a new approach. Frontiers in Ecology and the Environment, 3(7): 383-389. DOI: 10.1890/1540-9295(2005)003[0383:ROISUT]2.0.CO;2

Seddon PJ, Armstrong DP, and Maloney RF. 2007. Developing the science of reintroduction biology. Conservation Biology, 21(1): 303-312. DOI: 10.1111/j.1523-1739.2006.00627.x

Seigel RA, and Dodd CK Jr. 2000. Manipulation of turtle populations for conservation: halfway technologies or viable options? In Turtle conservation. Edited by MW Klemens. Smithsonian Institution Press, Washington, D.C. pp. 218-238. 
Shaver DJ. 1999. Kemp's Ridley sea turtle project at Padre Island National Seashore, Texas. In Proceedings of the Seventeenth Annual Gulf of Mexico Information Transfer Meeting. Edited by M Mckay and J Nides. US Department of the Interior, Minerals Management Service, Gulf of Mexico OCS Region, MMS 99-0042, New Orleans, Louisiana. 717 p.

Shaver DJ, and Rubio C. 2008. Post-nesting movement of wild and head-started Kemp's Ridley sea turtles Lepidochelys kempii in the Gulf of Mexico. Endangered Species Research, 4: 43-55. DOI: 10.3354/esr00061

Simon J, and Dörner H. 2014. Survival and growth of European eels stocked as glass- and farmsourced eels in five lakes in the first years after stocking. Ecology of Freshwater Fish, 23(1): 40-48. DOI: $10.1111 /$ eff.12050

Smeenk NA. 2010. The population ecology of a headstart supplemented population of diamondback terrapins (Malaclemys terrapin) at the Poplar Island Environmental Restoration Project in the middle Chesapeake Bay. M.S. thesis, Ohio University, Athens, Ohio. 71 p.

Smith RK, Pullin AS, Stewart GB, and Sutherland WJ. 2010. Effectiveness of predator removal for enhancing bird populations. Conservation Biology, 24(3): 820-829. PMID: 20067492 DOI: 10.1111/ j.1523-1739.2009.01421.x

Soorae PS (Editor). 2016. Global re-introduction perspectives: 2016. Case-studies from around the globe. IUCN/SSC Re-introduction Specialist Group, Gland, Switzerland, and Environment Agency-Abu Dhabi, Abu Dhabi, UAE. 276 p.

Spinks PQ, Pauly GB, Crayon JJ, and Schaffer HB. 2003. Survival of the western pond turtle (Emys marmorata) in an urban California environment. Biological Conservation, 113(2): 257-267. DOI: 10.1016/S0006-3207(02)00392-0

Stewart G. 2010. Meta-analysis in applied ecology. Biology Letters, 6: 78-81. PMID: 19776064 DOI: $10.1098 / \mathrm{rsbl} .2009 .0546$

Turtle Conservation Coalition. 2011. Turtles in trouble: the world's 25+ most endangered tortoises and freshwater turtles. IUCN/SSC Tortoise and Freshwater Turtle Specialist Group, Turtle Conservation Fund, Turtle Survival Alliance, Turtle Conservancy, Chelonian Research Foundation, Conservation International, Wildlife Conservation Society, and San Diego Zoo Global, Lunenburg, Massachusetts. 58 p.

Ultsch GR, Draud M, and Wicklow B. 2007. Post-emergence movements and overwintering of snapping turtle, Chelydra serpentina, hatchlings in New York and New Hampshire. The Canadian Field-Naturalist, 121(2): 178-181. DOI: 10.22621/cfn.v121i2.443

US Fish \& Wildlife Service. 2001. Bog turtle (Clemmys muhlenbergii), northern population, recovery plan. US Fish \& Wildlife Service, Hadley, Massachusetts. 109 p.

Van Leuven S, Allen H, Slavens K, and Anderson D. 2006. Western pond turtle head-starting and reintroduction, 2005-2006 annual report, project no. 200102700 (BPA report DOE/BP-00023926-1). Washington Department of Fish and Wildlife, Olympia, Washington. 15 p.

Vander Haegen WM, Clark SL, Perillo KM, Anderson DP, and Allen HL. 2009. Survival and causes of mortality of head-started western pond turtles on Pierce National Wildlife Refuge, Washington. Journal of Wildlife Management, 73(8): 1402-1406. DOI: 10.2193/2008-484 
Vermont Fish \& Wildlife Department. 2009. Eastern spiny softshell turtle recovery plan, January 2009. Vermont Fish \& Wildlife Department, Agency of Natural Resources, Waterbury, Vermont. 57 p.

Whitear AK, Wang X, Catling P, McLennan DA, and Davy CM. 2017. The scent of a hatchling: interspecies variation in the use of chemosensory cues by neonate freshwater turtles. Biological Journal of the Linnean Society, 120(1): 179-188. DOI: 10.1111/bij.12855

Wieser W. 1994. Cost of growth in cells and organisms: general rules and comparative aspects. Biological Reviews, 69(1): 1-33. PMID: 8193215 DOI: 10.1111/j.1469-185X.1994.tb01484.x

Wilbur HM, and Morin PJ. 1988. Life history evolution in turtles. In Biology of the reptilia. Edited by C Gans and RB Huey. Alan R. Liss, Inc., New York City, New York. pp. 391-440.

Woody JB. 1990. Guest editorial: is 'headstarting' a reasonable conservation measure? On the surface, yes; in reality, no. Marine Turtle Newsletter, 50: 8-11. 